December - 2006

\title{
Partner Power: A study of two distance education consortia
}

\author{
Anne Banks Pidduck and Tom Carey \\ University of Waterloo, Canada
}

\begin{abstract}
This research reports findings from a study which explored the process and criteria of partner selection - how and why partners are chosen - for two distance education consortia. The researchers reviewed recent literature on partnerships and partner selection. Two Canada-wide distance education consortia were identified as large-scale case studies for investigation of the research theory. A total of 34 informants were contacted. Written business plans, contracts, documents, partner network diagrams, and 231 archival emails from 36 correspondents were collected and analyzed for the two consortia. The research identified four criteria that influence why specific partners are chosen: requirements, resource availability, social network, and reputation. These findings suggest that the formation of partnerships and the process of partner selection are both very complex.
\end{abstract}

Keywords: distance education; higher education; e-learning; online learning

\section{Partner Selection Issues in Distance Education Consortia}

Alliances, collaborations, and consortia are becoming ubiquitous in today's competitive environment (Doz \& Hamel, 1998; Barringer \& Harrison, 2000; Das \& Teng, 2000). Partner selection is of significant importance in the success of these collaborative interorganizational relationships (Beamish, 1987). The current problem is not whether to partner, but to decide among a variety of collaborators (Beamish, 1987; Angeles \& Nath, 2000; Dussauge, Garrette, \& Mitchell, 2000). How do organizations find and choose among a number of potential partners? How do organizations choose the best partner for a particular situation? "You don't want to be left standing alone, but you also want to secure the best partners you can and avoid being pulled down by someone else’s poor partnering” (Kanter, 2001, p. 138).

Our domain of interest is the field of education, in particular distance education in Canadian universities. This research investigated alliances and consortia among distance education providers. There is an abundance of educational literature on collaborations and partnerships, but the majority is personal learning and mentoring relationships. Some of this literature has been explored for factors that may be extended to the organizational relationships of interest in this study.

The overall objective of this research was to understand the partner selection process in two Canadian distance education consortia. This work explored partner selection through interviews, 
written artifacts, contracts, email, and other data. Through this exploration, discovered was the cyclic processes of deal-making, organizational approval, and partner negotiation. This research also identified critical influences that may have contributed to partner selection such as reputation and social network.

The first two sections of this paper provide background on the issues around which the case studies were focused and the methods which were employed. The overview of issues in the next section examines recent work in interorganizational relationships and partner selection from the broader management science literature, with subsequent examination of issues specific to consortia in distance education. The section on research design and methodology includes a discussion of qualitative design and case study research, as well as the specific process followed with the distance education consortia of this study. The two case study sections provide a highlevel view of data from Consortium 1 and 2. Analysis of Results discusses the results from both consortia and suggestions for future research. The Conclusions section provides a summary of the insights from this research study and some of their implications for distance education.

\section{Issues in Interorganizational Relationships and Partner Selection}

Interorganizational relationships help organizations create value by combining resources, sharing knowledge, increasing speed to market, and gaining access to foreign markets (Yan \& Gray, 1994; Doz \& Hamel, 1998; Dussauge, Garrette, \& Mitchell, 2000) Since 1987, the number of strategic alliances worldwide has grown by 25 percent annually (Bleeke \& Ernst, 1995; Harbison \& Pekar, 1998). Business alliances for cooperative or competitive advantage have become ubiquitous over the past 10 years (Davidow \& Malone, 1992; Landay, 1996; Barringer \& Harrison, 2000). Firms are purchasing in bulk from each other, manufacturing cooperatively (Chen \& Ross, 2000), servicing each other's customers, and so on in reciprocal agreements that are meant to increase revenue and profit for both partners.

Alliances have limited lifespans (Ajami \& Khambata, 1991). The median lifespan of alliances is about seven years, failure rate is high, and seven out of 10 joint ventures fall short of expectations and thus disband (Kanter, 1994; Bleeke \& Ernst, 1995). In spite of the disadvantages ". . . factors such as dependence on external resources or pressure for legitimacy can lead organizations into difficult alliances ..." (Barringer \& Harrison, 2000, p. 369). Alliances between competitors require a fair balance of skills, market access, and capital between the companies (Bleeke \& Ernst, 1994).

A number of authors have identified positive reasons for becoming involved with other organizations. The initial advantages are economic - gain access to a particular resource, economies of scale, and risk and cost sharing, particularly in a large venture. Alliances can provide access to foreign markets, can enable corporate learning, and can pool resources for the development of new, better, bigger products and services. Speed to market, structural and regulatory flexibility, lobbying power, and market power for competitive advantage all add to the potential advantages of partnerships. Alliances can be social entities, useful for personal and political motivations. Some alliances form as a result of personal ties between key decision makers. Conversely, some alliances may be avoided because of mistrust or personal differences among firms or decision-makers (Barringer \& Harrison, 2000). 


\section{Research on Partner Selection}

Partner selection literature is limited and focused on the criteria for choosing partners rather than on the process of partner selection. Most articles assume a rational decision-making process based on specific selection criteria. In fact, computers, search engines, and pattern matching are now being used for partner selection. For example, potential collaborators can be found through a software program that compares individual patterns of Web browsing. Access logs are graphed and compared, so that similarities and differences can be discovered. Mechanisms to overcome privacy concerns are noted. Visual designs are used to enable users to explore possible matching interests with other users (Payton, 1999).

Existing partner selection literature assumes a straight-line start-to-finish selection process (Duysters, Kok, \& Vaandrager, 1999; Angeles \& Nath, 2000; Barringer \& Harrison, 2000; Hitt, Dacin, Lavitas, Arregle, \& Borza, 2000; Saffu \& Mamman, 2000). Depending on the motivation of the alliance as a whole, particular partner characteristics will be more or less valuable. A logical selection criteria is developed, often prioritizing the partner characteristics of interest. Finally, a partner is rationally selected meeting all of the criteria.

Based on the preceding theories, Table 1 identifies a variety of partner selection criteria.

PARTNER SELECTION CRITERIA

Personal contact and previous knowledge of partner

Strategic commitment and support

Flexibility and willingness to adjust to change

Communications including willingness to talk and make the alliance work

Personal interest in the alliance

Financial assets available to put into the partnership

Technical capabilities, people or machines needed for the alliance

Intangible assets; other items of interest

Willingness to share expertise and teaching

resources

Unique competencies

Local market knowledge, access
SOURCE

Barringer \& Harrison, 2000

Angeles \& Nath, 2000

Angeles \& Nath, 2000

Angeles \& Nath 2000

Duysters, Kok \& Vaandrager, 1999

Hitt, Dacin, et al. 2000; Saffu \& Mamman 2000

Hitt, Dacin, et al., 2000; Saffu \& Mamman 2000

Hitt, Dacin, et al., 2000

Hitt, Dacin, et al., 2000; Saffu \& Mamman 2000

Hitt, Dacin, et al., 2000

Hitt, Dacin, et al., 2000; Saffu \& Mamman

2000

Table 1. Partner Selection Criteria 


\section{Partner Selection Issues in Distance Education}

Distance education provides a number of opportunities for partner selection - educational institutions, students, countries, industrial partners, and so on. An e-learning evolution paper in 2001 (Johnston, 2001) promoted a pan-Canadian coordination of e-learning. Our research identified 20 large-scale educational partnerships worldwide, many of which included distance education. Numerous additional alliances are regional within provinces, states or countries and an increasing number of worldwide partnerships are forming. There have been a number of online learning initiatives including the Canlearn database (www.canlearn.ca) and Schoolnet in the United States (www.schoolnet.com). As the business world moves to a global model, the push for global education increases.

While our focus in the case studies is limited to a single country, a number of university consortia were in formation in the same timeframe. For example, Universitas 21, a global alliance, is an international network of 20 leading research-intensive universities in eleven countries, including McGill and University of British Columbia in Canada (www.universitas21.com). Its purpose is to facilitate collaboration and cooperation between the member universities and create entrepreneurial opportunities for them on a scale that none would be able to achieve operating independently or through traditional bilateral alliances. Membership is determined by a Nominations and Membership Committee. This alliance prompted early concerns over the commitment of large sums of money and the licensing of names and logos to an outside organization (Maslen, 2001).

Some research questions of interest were found in (Saltiel, Sgroi, \& Brockett, 1998), adapted from (Baldwin \& Austin, 1995):

- How do partners find each other and initiate their work?

- What qualities does each partner look for or find in the other? Why is this important? How does it contribute to the dynamic?

- What factors from the particular setting or context affect the success of the partnership?

- How do partnerships change over time?

- What stages do they pass through?

The above questions were related to research on faculty collaboration, using individual researchers as the unit of analysis. The researcher adapted some of these questions to interorganizational relationships, using the organization as the unit of relevance. This research is interested in particular in 'Why do partners choose each other?' and 'What qualities does each partner look for or find in the other?'

The researcher has chosen to not focus on the notions of power, politics, time, and trust in decision-making and in partner selection, other than as they were raised by interviewees and affected the specific decision instances of the research. A detailed discussion of these issues is outside the scope of this work. Power is difficult to identify, measure, and put into practice (Pfeffer, 1992). 'Politics' may be defined as competition between competing interest groups or individuals for power and leadership (Merriam-Webster, 2004). In the context of a consortium, however, politics may mean pressure to join the group if a favour is owed, thereby causing 
confusion. Time to make a decision and length of time that the alliance will last are both beyond the scope of this work. Trust is a large enough issue that it has been explored in many other articles, and again is outside the scope of this work. Each of these items could be studied in their own right as potential selection criteria.

\section{Case Study Research Design and Methodology}

A qualitative design approach was chosen for this research beginning with a focused literature review to identify key issues. Qualitative research is interdisciplinary, crosscutting the humanities and the social and physical sciences and is well suited to studies in education (Lancy, 1993; Creswell, 1994). Qualitative work allows reality to be subjective with multiple viewpoints, evolving decisions, and emerging design categories identified during the research process (Firestone, 1987; Marshall \& Rossman, 1989). Early in the work, three people who had been involved in software development or distance education partnerships or both were informally interviewed. These initial interviewees were known to the researchers and provided valuable insight into how their partner selection had worked. This limited empirical view was compared to the theoretical ideas of the literature and both were used to develop a Partner Negotiation Model (Pidduck, 2006). The work was continued with a multiple case study approach, using two Canadian education consortia as the cases.

The specific partnerships studied were two Canada-wide distance education consortia. Consortium 1 included 13 Canadian universities during the study period and focuses on open and distance teaching and learning. Consortium 2 is comprised of eight Canadian universities with a broader academic research mandate around distance education. Due to different motivations of the partners, Canada ended up with two consortia rather than one.

Case study information was gathered from a number of sources. The most significant resources for Consortium 1 were formal interviews with three Consortium 1 partners, discussions with four university contacts, email interviews, Consortium 1 organizational documents, Consortium 1 webpages, and government request for proposal (RFP) and funding documents. The email interviewees were aware that their information would be used in this research study and were offered final study results. For Consortium 2, the majority of the information came from formal interviews with three Consortium 2 partners, informal discussions with two university contacts, historical emails, Consortium 2 documents, press releases, and webpages. The historical emails provided generic background information and timelines only for this research. The combination of various types of data collected from multiple sources reduced bias and added depth to the final study results (Bogdan \& Biklen, 1992; Merriam, 1988).

Informants were purposefully selected for their knowledge of alliances or consortia in the distance education domain. All interviewees were at a director level or higher, generally in a group related to education, teaching, learning, and technology. Some subjects were previously known to the researcher, which added a dimension of informality and potentially additional depth of understanding for the study. The researcher contacted at least one key informant from each partner in Consortia 1 and 2. The purpose was discussed with them so that they had a good idea of the interview focus, which was partner selection within their consortium. For those partners willing to be interviewed, an interview schedule was established to verify the day and time for an interview. Some contacts asked for questions ahead of time and these were provided only if requested. Interviews occurred in a variety of settings: university offices, hotel lobby, hotel bar, park bench on a busy street, and hotel meeting room. Researcher observation notes on the settings 
and other descriptive data were also recorded. Some partners who were not available in person provided information by telephone or email and authorized its use for this work.

\section{Consortium 1}

Consortium 1 is a partnership of universities across Canada, committed to delivering universitylevel programs that can be completed from anywhere in the country or beyond. As of June 2006, Consortium 1 had 12 institutional partners from across Canada. The consortium identifies accredited courses, provides access to courses developed by partner universities, provides a clearing house for students wanting to mix and match courses from various universities, facilitates transfer credit, and generally creates sharing efficiencies.

There was a three-stage process of partner selection in Consortium 1. The 'early birds' who were organizing the consortium got in first, set the partnership criteria, and selected the educational areas of interest for themselves. Then the alliance was opened up to other universities who would take the educational areas that had not yet been covered. Finally, when the partnership needed to grow, it was opened to anyone who wanted to join.

Consortium 1 started with discussions of the need for a Canadian Open University. The general feeling was that a distance education consortium was needed to prevent Canadian universities from joining American, European, or Asian consortia. Interest from non-Canadians, as well as other world-wide collaborative efforts, inspired the Canadians to start their own online distance education collaboration. Funding for a potential Canada-wide consortium was pre-arranged in the form of a 'commitment in principle' from provincial and federal governments before Consortium 1 began.

The original discussants were three of Canada's leading distance education specialists. Program offerings from these three organizations made up the core of Consortium 1 at its outset. The organizing committee approached 12 other Canadian universities to become a 'founding member' of Consortium 1. Potential Consortium 1 partners needed strong distance education programs that could be offered nationally and something unique that everyone else did not offer. The focus of Consortium 1 was to be 'program-based' rather than 'distance education course listings' as was already being done with regional consortia.

Consortium 1 Fundamental Principles emphasized the view of what Consortium 1 could be - only complementary programs with openness and flexibility. The open enrolment philosophy meant that many universities with very high and tight enrolment standards might end up with substandard students in individual courses if not in entire distance education programs. Two large research-intensive universities told the Consortium 1 organizers that they could not sell Consortium 1 principles in their institutions, because research universities had different pedagogies than open universities. They thought that the idea of a Canada-wide distance education consortium was a good idea, but needed more focus on research. After the organizational meeting, Consortium 1 incorporated with five distance education institutions as founding members and a seat on the board of directors.

Shortly after the formation of Consortium 1, Industry Canada put out a RFP for Campus Canada funding, looking for universities and colleges to work together to provide flexible, seamless, portable learning opportunities for federal employee groups. The government got three responses to the RFP - one from Consortium 1, one from a group of community colleges called the Canadian Virtual College (CVC), and the third one from a group of three Atlantic universities. 
The Atlantic universities then joined Consortium 1, so that it would be easier for them to obtain federal funding. Consortium 1 worked with CVC so that all three groups ended up sharing the federal funding.

In year two, Consortium 1 grew to nine partners with the board of directors made up of the president or an appointee from each of the member institutions. There was also one additional provider university, which advertised its distance education offerings with Consortium 1, but did not pay member dues. By year four, there were 13 Consortium 1 partners. Of those, 10 were full members and three were associates. As of year five, there were 250 programs and 2,000 courses being offered through Consortium 1.

There are different degrees of commitment and participation from the various partner institutions, depending on the time, energy and money that they will provide for Consortium 1. Universities who have fewer programs to offer and those who have joined recently are less active. Institutions with only one course or a small number of courses to offer within Consortium 1, are not required to pay full fees. Such institutions are not shareholders in Consortium 1 and do not attend board meetings. The degree of participation within Consortium 1 goes to some institutions by virtue of the people involved who sit on the advisory committee. This supports the idea of the real partner as the 'person,' not the 'institution.'

\section{Consortium 2}

Immediately after the Consortium 1 inaugural meeting, three Ontario universities began discussing a different type of distance education consortium with a significantly broader and deeper academic mandate than Consortium 1. The new proposal focused on technology, quality, depth, breadth, research, and active collaboration. Members of Consortium 2 were recognized as research intensive universities with a strong presence in the delivery of Internet-enhanced learning. The three founding members invited additional universities with similar profiles as innovative research institutions to join. A Memorandum of Understanding (MOU) established the intention of member institutions to work collaboratively to enhance high-quality Internet-based programs and to integrate scholarly values and culture into our learning and teaching. Membership was open to other Canadian research universities who can add value and who share our traditions of quality, innovation, accessibility, and outreach. Funding was explicitly mentioned in the MOU. An annual membership fee of CDN \$5000 was proposed.

Contacts from two western universities agreed that an academic focus of research into teaching and learning through technology was important as was an interactive approach. Concern was expressed, however, about a clear definition for a 'research university' and the issue of new partner selection - 'how and at what stage' would you invite others if they wished to join? One of the western universities joined and the consortium identified a target to add three more universities by the end of year one, providing a truly national, coast-to-coast collaboration. At this time, two operational thrusts were recognized - Consortium 2 web presence focused on collaborative development of high-quality Internet-enabled programs, and the Consortium 2 Institute focused on integrating scholarly values and culture with longer-term impacts. Two partner selection issues at this time were that federal funding required Canada-wide coverage and that the west coast partners were worried that Ontario may be overly controlling the partnership.

Quebec and Atlantic partners were proactively sought to provide the broad geographical coverage necessary for a truly Canadian consortium. An appropriate Quebec partner was not found, but an 
Atlantic partner with strong distance education research experience was added. Four partners were added later from the western provinces, broadening the consortium's geographical reach.

In year three, Consortium 2 was officially announced as a national collaboration of eight major Canadian universities. The universities included four western universities, three Ontario universities, and one Atlantic university. The Consortium 2 also promised its first research project with an online learning environment, as well as co-development of courses among universities. The website also promised a culture of research and scholarship tied to technology-enhanced learning, development of students' capabilities and ongoing development of faculty, culminating in a network of expert faculty members. This indicated a very different focus and agenda from Consortium 1.

\section{Analysis of Results}

Partner selection results are provided in varied formats and organized into a number of areas, following mixed research methods. Findings were validated, as suggested by (Creswell, 2003), with multiple cases, rich narrative descriptions, patterns, different sources of data, and external auditing. As the data was collected, it was read through at a high level to obtain a general sense of the work. At this point, data from other sources were read, organized chronologically, and written into the two case study narratives. As expected, there was a definite sense of community and social network contact in order to find appropriate partners. Reputation was mentioned several times as an issue in partner selection. The term 'reputation' is used here as expressed by interviewees. Brewer, Gates, and Goldman (2002) use the term 'prestige' in their discussion of U.S. higher education. Unrelated to the specific issue of partner selection, many of the interviewees expressed concern that there were two distance education consortia in Canada and they would prefer to see only one. Since the two consortia are separated in the minds of some participants by level of education and research (or quality of both), the issue actually is relevant to the partners chosen or not chosen for each partnership. Also tied to this issue was the notion of government funding. Both sides seemed to feel that funding would be easier to obtain for one united consortium.

Consortium 1 membership has changed dramatically over the years. Consortium 1 began with five members and grew to a high of 13 members in year four, and is currently at 12 members. Conversely, Consortium 2 began with eight members and currently remains at that steady state. The interests and motivation of the partners are very different as well. Consortium 1 partners are interested in online course development and offerings and in generating revenue from the partnership. Consortium 2 partners are more interested in research and scholarship related to online teaching and learning, co-development of courses, and faculty development.

A strong social network is evident, in that many of the partners knew each other and worked together before either consortium was established. As well, many new contacts were made through the partnerships. This research documented 86 people known to be involved in either the Consortium 1 or the Consortium 2 partnership or both. Many of those in Ontario already knew the Alberta and British Columbia people before Consortium 1 and vice versa. At least three western presidents and vice presidents had previous academic appointments in the Maritimes and in Ontario.

The Consortium 1 partners seemed close to very each other and very specific in terms of the good that the Consortium 1 partnership was doing for their organizations. All of the interviewees could 
name specific things that had been accomplished through Consortium 1. They could all identify collaborative distance education course offerings that had been developed with Consortium 1.

Consortium 2 partners were less sure of the need for and benefit of the partnership for their organizations. Since this partnership operates at a higher level, related to collaborative research rather than specific distance education offerings, this should not be surprising. Several collaborative research projects were mentioned that were ongoing or that were at the proposal stage. Because collaborative research had been going on before Consortium 2, however, the interviewees were unsure of the positive impact of Consortium 2 on this work.

A change proposed by many partners, but which is seemingly difficult to implement, is to have the two consortia join or work together. One suggestion was to have various 'tiers' within one partnership. That is, have a high-quality research group in the universities that are interested, but also have a distance education program and course development group at the same universities. That would allow both a Consortium 1 and 2 flavour within the one consortium.

A number of Canadian universities were approached to join either Consortium 1 or 2 or both, but declined. One university already had a large number of established international and provincial partnerships, so at that point perceived no advantage for them. At least seven large universities declined because they do not have strong distance education programs.

In contrast to previous work, these results show the complex and multi-faceted nature of partner selection with multiple negotiation cycles and irrational selection criteria. These findings showed two patterns: one related to process and the second related to selection criteria. The process showed multiple cycles of deal-making, partner negotiation, and organizational approval rather than the simple straight-line decision-making process shown in much partner selection literature. The selection criteria findings showed a number of decisive factors that influenced the final choice of partner. As well as the need to meet the condition of documented requirements, partner selection was also influenced by resource availability, social network, and reputation.

The deal-making cycles in these results showed multiple sponsors and drivers. External funding was needed for both consortia as well as high-level organizational approval for the partnership itself. Cycles of organizational approval appeared both in this early partnership formation and later as new partners were added and the partnership changed. Key partners were needed to fulfill specific partnership roles or to attract new partners. Partners were identified first based on their match to explicit requirements. As part of the selection process, however, additional criteria influenced the specific partners that were chosen. Some partners were selected only after the potential first-choice partners had declined their offers. Many partners were chosen because they were already known by others in the partnership, while others were distinguished and proposed because of their reputation.

Overall, results identified the following issues:

1. Partner selection is more complex than past research has described

2. There are gaps in the research on partner selection

3. Existing partner selection models do not adequately describe what was happening 
4. Partner selection criteria are not based solely on rational analysis of goals and requirements

5. One challenge of partner selection is the large number of people involved in partner selection and partnerships in general. This social network and communication are important in identifying and selecting partners

\section{Reputation can be very important in partner selection}

For future research, resource availability could be studied on its own since several partners were observed that had been chosen only because other partners were already busy or not interested in the partnership at hand. This indicates the potential of a first choice or second choice partner. The second choice only seems to be included when the first choice is not available for whatever reason.

A number of levels of partner and partnership emerged from this work, but were too complex to include at this time. For example, partnerships can be based on verbal agreements among highlevel executives. The actual partnership formation and operation are then delegated to lesser executives, middle managers, and finally frontline personnel. Each of these levels of responsibility has a different focus on the partnership. Each level has work to do to make sure that the partnership develops appropriately and evolves to the advantage of each organization and to the advantage of the partnership itself.

All work to be done, with or without partnerships, is constrained at different institutions, depending on resources of time, money, and expertise. Government constraints are tied to funding priorities such as distance education, mobile technologies, Canada-wide networks, and coast-tocoast coverage. There was some evidence in this research of institutions trying to fit their needs to government constraints and vice versa. A study of a number of funding opportunities, including constraints and funding fit on both sides, might provide some interesting results which could help both sides better negotiate their future requirements.

\section{Conclusions}

The research questions that were answered in this work focused on 'how and why' partners are chosen. These questions turned out to be non-trivial as the researcher found that the formation of partnerships and the process of partner selection are both very complex. The literature review provides a synopsis of previous work on interorganizational relationships, decision-making, and partner selection.

The Canadian distance education partnerships described in the case study narratives provide both positive and negative lessons learned. Partnership formation and initial partner selection information can help other institutions with similar issues. Information on later partners who were added or who dropped out can provide insight as to what worked and did not work in these cases. External funding, governing structure, and social network emerged as extremely important issues for these partnerships, so could again provide a solid background for new partnerships just starting out.

The most important contribution of this research to distance education theory is an increased understanding of partner negotiation and selection from an organizational perspective. The research is unique with the focus on partner selection and processes. Key people and institutions 
are major factors in partnership formation. Social networks and reputation are key elements in partner choice.

The Canadian distance education field cases used as the domain also provide a distinctive perspective for this research. These cases provide deep and narrow research that may later be extended and generalized into a partner selection theory in combination with the existing literature and models noted previously. This work will also be of interest to researchers who want to know how certain partnerships form. The study will be of interest to governments and other organizations involved in establishing standards and limitations for collaborations, so that they can better delineate partner selection processes and choice criteria.

One contribution of this study to the distance education practice will be to provide managers with an aid in partner selection decisions. The list of partnership issues and organizational and alliance characteristics resulting from this study can assist managers in implementing, or considering, interorganizational relationships. The study can provide both a rich description of partner selection issues and an analysis of the relationship between these issues and real-world consortia. At an individual organization level, the results of this work can save time and aid the decisionmaking process in terms of partner selection. By providing information about the process and factors to consider as important for partnerships, this work may allow organizations to choose among potential collaborators more easily, more fairly, and in a more structured manner than a typically ad hoc approach.

This work makes a number of contributions to an understanding of partnerships and partner selection. Although we used two specific Canadian distance education consortia for our domain subjects, we expect that some of the results may be used in a broader international context. The literature review provides a summary and overview of current alliance and partner selection literature and shows deficiencies and gaps in that literature. Case study narratives offer deep, interesting insight into two specific cases of Canadian consortia. The results of the case study data applied to theory give further understanding of partnerships. Finally, the number of issues identified for future work verify the complexity of this research and give other researchers a better understanding of what still needs to be done and how it might be undertaken.

\section{References}

Ajami, R., \& Khambata, D. (1991). Global Strategic Alliances: the New Transnationals. Journal of Global Marketing 5(1), 55-69.

Angeles, R., \& Nath, R. (2000). An Empirical Study of EDI Trading Partner Selection Criteria in Customer-Supplier Relationships. Information and Management 37(5), 241-255.

Baldwin, R. G., \& Austin, A. R. (1995). Toward a Greater Understanding of Faculty Research Collaboration. Review of Higher Education 19(1), 45-70.

Barringer, B. R., \& Harrison, J. S. (2000). Walking a Tightrope: Creating value through interorganizational relationships. Journal of Management 26(3), 367-403.

Beamish, P. W. (1987). Joint Ventures in LDCs: Partner selection and performance. Management International Review 27(1), 23-37. 
Bleeke, J., \& Ernst, D. (1994). Collaborating to compete. In H. Mintzberg \& J. B. Quinn (Eds.) Directors and Boards (pp. 174-8). Upper Saddle River, NJ.: Prentice-Hall

Bleeke, J., \& Ernst, D. (1995). Is your strategic alliance really a sale? Harvard Business Review 73(1), 97-105.

Bogdan, R. C., \& Biklen, S. K. (1992). Qualitative Research for Education: An introduction to theory and methods. Boston, MA.: Allyn \& Bacon.

Brewer, D. J., Gates, S. M., \& Goldman, C. (2002). In Pursuit of Prestige: Strategy and competition in U.S. Higher Education. Santa Monica, CA.: Transaction Publishers.

Chen, Z. Q., \& Ross, T. W. (2000). Strategic Alliances, Shared Facilities, and Entry Deterrence. Rand Journal of Economics 31(2), 326-344.

Creswell, J. W. (1994). Research Design: Qualitative and quantitative approaches. Thousand Oaks, CA.: Sage.

Creswell, J. W. (2003). Research Design: Qualitative, quantitative, and mixed methods approaches. Thousand Oaks, CA.: Sage.

Das, T. K., \& Teng, B. S. (2000). A Resource-Based Theory of Strategic Alliances. Journal of Management 26(1), 31-61.

Davidow, W. H., \& Malone, M. S. (1992). The Virtual Corporation: Structuring and revitalizing the corporation for the 21st century. New York: HarperCollins.

Doz, Y. L., \& Hamel, G. (1998). Alliance Advantage. Boston, MA.: Harvard Business School Press.

Dussauge, P., Garrette, B., \& Mitchell, W. (2000). Learning from Competing Partners: Outcomes and durations of scale and link alliances in Europe, North America, and Asia. Strategic Management Journal 21(2), 99-126.

Duysters, G., Kok, G., \& Vaandrager, M. (1999). Crafting Successful Strategic Technology Partnerships. R\&D Management 29(4), 343-351.

Firestone, W. A. (1987). Meaning in Method: The rhetoric of quantitative and qualitative research. Educational Researcher 16(7), 16-21.

Harbison, J. R., \& Pekar, P. (1998). Smart Alliances. San Francisco: Jossey-Bass.

Hitt, M. A., Dacin, M. T., Lavitas, E., Arregle, J., \& Borza, A. (2000). Partner Selection in Emerging and Developed Market Contexts: Resource-based and organizational learning perspectives. Academy of Management Journal 43(3), 449-467.

Johnston, D. (2001). The e-Learning E-volution in Colleges and Universities: A pan-Canadian challenge. The Advisory Committee for Online Learning. Ottawa: Industry Canada. 
Kanter, R. (1994). Collaborative Advantage. Harvard Business Review 72(4), 96-108.

Kanter, R. M. (2001). Evolve! Boston: Harvard Business School Press.

Lancy, D. F. (1993). Qualitative Research in Education: An introduction to the major traditions. New York: Longman.

Landay, W. (1996). Rediscovering Strength in Numbers: Extended enterprises spell success. Enterprise Reengineering, May.

Marshall, C., \& Rossman, G. B. (1989). Designing Qualitative Research. Newbury Park, CA.: Sage.

Maslen, G. (2001). As Deadline Approaches, Universitas 21 Seeks Funds for its Online Institution. The Chronicle of Higher Education 22(47).

Merriam, S. B. (1988). Case Study Research in Education: A qualitative approach. San Francisco: Jossey-Bass.

Merriam-Webster (2004). Merriam-Webster Collegiate Dictionary online. Retrieved November 20, 2006 from: http://www.m-w.com/

Payton, D. (1999). Dynamic collaborator discovery in information-intensive environments. Paper presented at Electronic Symposium on Computer-Supported Cooperative Work, National Institute of Standards and Technology, June 17-19, Gaithersburg, MD.

Pfeffer, J. (1992). Understanding the Role of Power in Decision Making. Classics of Organization Theory. Belmont, CA.: Wadsworth.

Pidduck, A. B. (2006). Issues in Supplier Partner Selection. Journal of Enterprise Information Management 19(3), 262-276.

Saffu, K., \& Mamman, A. (2000). Mechanics, Problems and Contributions of Tertiary Strategic Alliances: The case of 22 Australian universities. Library Consortium Management 2(2), 44-53.

Saltiel, I.M., Sgroi, A., \& Brockett, R. G. (1998). The Power and Potential of Collaborative Learning Partnerships: New directions for adult and continuing education. San Francisco: Jossey-Bass.

Yan, A., \& Gray, B. (1994). Bargaining Power, Management Control, and Performance in United States/ China Joint Ventures: A comparative case study. Academy of Management Journal 37(1), 1478-1517.

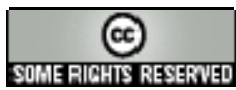

